\title{
Penentuan Dosis Optimum Pemupukan Nitrogen pada Tanaman Kolesom (Talinum triangulare (Jacq.) Wild.)
}

Determination Optimum Dosage of Nitrogen on Ginseng Crop (Talinum triangulare (Jacq.) Wild.)

\author{
Hardi Satria Tarigan, Juang Gema Kartika* dan Anas D. Susila
}

\author{
Departemen Agronomi dan Hortikultura, Fakultas Pertanian, Institut Pertanian Bogor \\ (Bogor Agricultural University), J1. Meranti, Kampus IPB Darmaga, Bogor 16680, Indonesia \\ Telp. \& Faks. 62-251-8629353 e-mail agrohort@apps.ipb.ac.id \\ *Penulis Korespondensi : juangkartika@yahoo.com \\ Disetujui : 19 September 2018 / Published Online 2 Januari 2019
}

\begin{abstract}
The aim of this research was to determine the optimum dosage of nitrogen fertilizer that can characterize the maximum yield on ginseng crop production using irrigation system, spray Hose. The experiment took place at University Experimental Farm, Department of Agronomy and Horticulture, Faculty of Agriculture, Bogor Agricultural University. Planting material in this reserach used ginseng stem cuttings. This research used one factor Randomized Complete Block Design (RCBD) which rate of nitrogen fertilization with five level rate of fertilizer with four replications. Rate of fertilizer used consisted of $0 \%$, $50 \%, 100 \%, 150 \%$ and $200 \%$, where $100 \% \mathrm{~N}=67.5 \mathrm{~kg} \mathrm{ha}^{-1}$, based on fertilizer recommendations in previous research. Each experimental unit planted in plots with a size of $5 \mathrm{~m} \times 1 \mathrm{~m}$ and spacing $40 \mathrm{~cm} \times 25$ $\mathrm{cm}$, each plot consisted of 25 plants. The first harvesting is done when the plant is 30 days old after planting. The result of this study showed that $N$ fertilization with different rates of $0 \%, 50 \%, 100 \%, 150 \%$, $200 \%$ increased quadratically wet weight of stover, header, stem and increased linearly leaves weight. Recommendation rate of $\mathrm{N}$ fertilizer is $108,45 \mathrm{kgN} \mathrm{ha}^{-1}$.
\end{abstract}

Keywords: yields, leafy vegetable, herb

\begin{abstract}
ABSTRAK
Penelitian bertujuan untuk menentukan dosis optimum pupuk nitrogen yang dapat memberikan hasil maksimum pada produksi pucuk tanaman dengan menggunakan sistem irigasi selang perforasi. Percobaan dilaksanakan di Kebun Percobaan University Farm, Departemen Agronomi dan Hortikultura, Fakultas Pertanian, Institut Pertanian Bogor, Darmaga. Bahan tanam yang digunakan pada penelitian ini adalah setek batang kolesom. Percobaan menggunakan rancangan RKLT (Rancangan Kelompok Lengkap Teracak) 1 faktor dan 5 taraf dosis pemupukan dan 4 ulangan. Dosis pupuk yang digunakan terdiri atas $0 \%, 50 \%, 100 \%$, $150 \%$ dan $200 \%$, dimana $100 \% \mathrm{~N}=67.5 \mathrm{~kg} \mathrm{ha}^{-1}$, berdasarkan rekomendasi pemupukan pada penelitian sebelumnya. Setiap satuan percobaan ditanam pada petakan dengan ukuran $5 \mathrm{~m} \mathrm{x1} \mathrm{m}$ dan jarak tanam $40 \mathrm{~cm}$ x $25 \mathrm{~cm}$, setiap petak terdiri dari 25 tanaman. Pemanenan pertama dilakukan ketika tanaman berumur 30 HST. Pemanenan dilakukan sebanyak 3 kali dengan interval panen 15 hari. Hasil penelitian menunjukkan perlakuan pemupukan $\mathrm{N}$ berbagai dosis $0 \%, 50 \%, 100 \%, 150 \%, 200 \%$ pada tanaman kolesom meningkatkan secara kuadratik bobot basah brangkasan, tajuk, batang dan meningkatkan secara linier bobot basah daun. Dosis rekomendasi pemupukan $\mathrm{N}$ adalah $108.45 \mathrm{kgN} \mathrm{ha}^{-1}$.
\end{abstract}

Kata kunci : produktivitas, sayuran daun, tanaman herbal 


\section{PENDAHULUAN}

Indonesia merupakan negara yang berada di kawasan tropis yang terkenal dengan keanekaragaman tanamannya. Dari keanekaragaman itu terdapat banyak tanaman yang memiliki manfaat sebagai tanaman sayuran sekaligus tanaman obat. Kolesom (Talinum triangulare (Jacq.) Wild.) merupakan tanaman tahunan yang pucuknya dapat dimanfaatkan sebagai tanaman sayuran dan akarnya bermanfaat sebagai obat. Kolesom merupakan tanaman yang berasal dari Amerika Tengah, dan diimpor ke Jawa lewat Suriname tahun 1915 (Rifai, 1994 ).

Pucuk kolesom dapat disebut sebagai sayuran fungsional karena mengandung beberapa bahan bioaktif yang dapat mempengaruhi fisiologis dan berdampak positif untuk kesehatan. Kolesom merupakan salah satu tanaman yang direkomendasikan sebagai tanaman sayuran murah yang dapat dijadikan sumber protein di Afrika, karena kemampuannya untuk mensintesis asam amino khususnya asam glutamate dan leusin (Fasuyi, 2006). Kolesom memiliki potensi sebagai bahan obat alami, karena mengandung bahan aktif seperti flavonoid, steroid, saponin dan tannin (Susanti et al., 2008). Salah satu falvonoid yang yang teridentifikasi yaitu antosianin yang bermanfaat sebagai pelindung tubuh dari kerusakan oksidatif dengan menghambat radikal bebas dan oksigen reaktif. Di Jawa Barat daun kolesom dimanfaatkan untuk lalap sebagai pengganti krokot (Portulaca oleracea L.) pada masakan etnis Sunda (Rifai, 1994). Manfaat dari tanaman kolesom yang beragam, menunjukkan bahwa pengembangan tanaman ini baik sebagai tanaman obat maupun sebagai tanaman sayuran sangat prospektif. Untuk mengantisipasi kebutuhan yang terus meningkat secara kontinyu diperlukan teknik pembudidayaan yang tepat.

Bagian tanaman yang dimanfaatkan sebagai sayuran dari tanaman kolesom adalah bagian pucuk. Salah satu faktor yang mempengaruhi produksi pucuk kolesom adalah lingkungan, seperti ketersediaan unsur hara, media tanam, dan ketersediaan air dalam tanah. Salah satu unsur hara makro yang butuhkan tanaman yaitu nitrogen (N). Wijaya (2008) menyatakan bahwa pemberian $\mathrm{N}$ pada tanaman akan mendorong pertumbuhan organ-organ yang berkaitan dengan fotosintesis yaitu daun. Tanaman yang memiliki suplai $\mathrm{N}$ dengan baik akan membentuk helaian daun yang baik dan kandungan klorofil yang tinggi, sehingga tumbuhan mampu menghasilkan karbohidrat dan asimilat yang tinggi sehingga cukup untuk menopang pertumbuhan vegetatif.

Untuk mendapatkan pucuk yang baik perlu dilakukan pemangkasan pada tanaman kolesom sebelum tanaman berbunga. Acquaah (2004) menyatakan bahwa pemangkasan pada bagian tunas pucuk (tunas apikal) akan mendorong pertumbuhan tunas-tunas lateral sehingga percabangan akan semakin banyak dan menghambat pertumbuhan tinggi tanaman. Pemanenan pucuk kolesom sebagai sayuran dapat dilakukan secara berulang kali dengan interval panen tertentu selama masa hidupnya (Sugiarto, 2006). Pertumbuhan tunas-tunas lateral membutuhkan ketersediaan unsur hara yang cukup untuk rejuvenasi. Ketersediaan hara yang cukup dapat dilakukan dengan usaha pemberian pupuk dengan dosis yang tepat.

Tanaman membutuhkan unsur hara yang cukup untuk memenuhi pertumbuhan dan perkembangannya, oleh karena itu pemupukan menjadi hal yang penting. Penggunaan pupuk yang berlebihan dapat bersifat toksik terhadap tanaman, mencemari lingkungan, dan meningkatkan biaya produksi. Diperlukan rekomendasi dosis pupuk optimal untuk meningkatkan produktivitas, dan tidak berlebih sehingga tidak mencemari lingkungan juga menekan biaya produksi usaha pertanian.

\section{BAHAN DAN METODE}

Percobaan dilaksanakan di Kebun Percobaan University Farm, Departemen Agronomi dan Hortikultura, Fakultas Pertanian, Institut Pertanian Bogor, Darmaga, Bogor pada bulan Juni hingga September 2016 dengan ketinggian tempat $240 \mathrm{~m}$ di atas permukaan laut (m dpl). Bahan tanam yang digunakan pada penelitian ini adalah setek batang kolesom. Alat yang digunakan pada percobaan ini adalah seperangkat Spray Hose, alat budidaya pertanian, timbangan digital, tali rafia, penggaris.

Rancangan yang digunakan pada setiap percobaan adalah RKLT (Rancangan Kelompok Lengkap Teracak) dengan satu perlakuan yaitu dosis pupuk nitrogen. Terdapat lima taraf dosis pemupukan $(0 \%, 50 \%, 100 \%, 150 \%$ dan $200 \%)$ dimana $100 \% \mathrm{~N}=67.5 \mathrm{kgN} \mathrm{ha}^{-1}$ atau $150 \mathrm{~kg}$ urea $\mathrm{ha}^{-1}$. Setiap perlakuan diulang sebanyak 4 kali sehingga terdapat 20 satuan percobaan untuk percobaan dengan perlakuan N. Setiap satuan percobaan ditanam pada bedengan dengan ukuran $5 \times 1 \mathrm{~m}$ dan jarak tanam $40 \times 25 \mathrm{~cm}$, Setiap petak terdiri dari 25 tanaman, sehingga seluruhnya terdapat 500 tanaman. Tanaman contoh merupakan 10 tanaman yang dipilih secara acak pada setiap petakan, sehingga terdapat 200 tanaman contoh. Pemeberian pupuk SP 36 dengn dosis $144 \mathrm{~kg} \mathrm{ha}^{-1}$ diberikan dengan tahapan dosis 
$96 \mathrm{~kg} \mathrm{ha}^{-1}$ pada 0 HST dan $24 \mathrm{~kg} \mathrm{ha}^{-1}$ pada 30 HST dan $60 \mathrm{HST}$. Pemeberian pupuk $\mathrm{KCl}$ dengn dosis $90 \mathrm{~kg} \mathrm{ha}^{-1}$ diberikan dengan tahapan dosis $60 \mathrm{~kg} \mathrm{ha}^{-1}$ pada $0 \mathrm{HST}$ dan $15 \mathrm{~kg} \mathrm{ha}^{-1}$ pada 30 HST dan 60 HST (Tabel 1).

Tabel 1. Dosis dan tahapan pemupukan pada kolesom

\begin{tabular}{lccc}
\hline Perlakuan & \multicolumn{3}{c}{ Waktu dan Dosis Pemberian Pupuk } \\
N (\%) & \multicolumn{3}{c}{ Urea } \\
\cline { 2 - 4 } & 0 HST & 30 HST & 60 HST \\
\hline & $---------------~$ kg ha $^{-1}$ & --------------- \\
0 & - & - & - \\
50 & 50.0 & 12.5 & 12.5 \\
100 & 100.0 & 25.0 & 25.0 \\
150 & 150.0 & 37.5 & 37.5 \\
200 & 200.0 & 50.0 & 50.0 \\
\hline
\end{tabular}

Keterangan: HST $=$ Hari Setelah Transplant

Pelaksanaan percobaan dimulai dengan pembibitan stek yang berupa stek batang dengan panjang $10 \mathrm{~cm}$. Dalam penelitian yang dilakukan Susanti et al. (2008) Bibit asal stek menghasilkan rata-rata tinggi tanaman terbaik yaitu $136 \%$ tinggi tanaman dari bibit asal benih. Stek ditanam dalam polybag 10x10 $\mathrm{cm}$ dengan media tanam yang digunakan yaitu topsoil, arang sekam, dan pupuk kandang. Pertama-tama akan dilakukan persiapan bedengan dengan melakukan pembersihan dan penggemburan lahan. Ukuran bedeng pada setiap satu satuan percobaan sebesar $5 \times 1 \mathrm{~m}$ dengan tinggi $20 \mathrm{~cm}$ dan jarak antar bedengan $50 \mathrm{~cm}$. Satu minggu sebelum penanaman lahan diberi pupuk kandang dengan dosis 20 ton $\mathrm{ha}^{-1}$ dan pengapuran dengan dosis 2 ton $\mathrm{ha}^{-1}$. Penanaman dilakukan apabila bibit yang berasal dari setek batang telah berdaun 2 helai dan membuka sempurna (Mualim 2009). Bibit ditanam pada bedengan yang telah disiapkan dengan jarak tanam $40 \mathrm{~cm} \times 25 \mathrm{~cm}$. Pada saat penanaman diberikan insektisida dengan bahan aktif karbofuran 3\% (dosis $10 \mathrm{~kg} \mathrm{ha}^{-1}$ ) sebanyak 4-5 butir/lubang tanam dengan tujuan untuk menghindari adanya serangan serangga yang akan mengganggu perakaran tanaman saat tanam. Pemeliharaan tanaman yang akan dilakukan meliputi penyulaman satu minggu setelah transplanting, penyiraman, penyiangan gulma, pengendalian hama penyakit dan roguing. Roguing yang dilakukan meliputi pemilahan tanaman yang tidak dikehendaki, seperti tanaman yang kerdil. Panen dilakukan dengan memetik atau memangkas pucuk tanaman kolesom yang belum berbunga sepanjang $\pm 15 \mathrm{~cm}$ yang diukur dari ujung daun bagian atas yang ditegakkan dari setiap cabang yang ada pada umur panen yang telah ditentukan. Pemanenan akan dilakukan dalam interval waktu 15 hari sekali (Anna, 2010).
Pemanenan pertama akan dilakukan saat tanaman berumur 30 Hari Setelah Transplan (HST).

Peubah yang diamati meliputi presentase hidup tanaman, jumlah pucuk panen pertanaman, bobot basah pucuk pertanaman, tinggi tanaman, bobot basah brangkasan, bobot basah tajuk, bobot basah daun, bobot basah batang dan bobot basah akar.

\section{HASIL DAN PEMBAHASAN}

\section{Kondisi Umum}

Berdasarkan data curah hujan BMKG pada bulan Juni 2016 hingga bulan Agustus 2016 (Lampiran 1), didapatkan jumlah hujan rata-rata selama dilakukannya penelitian (Juni - Agustus 2015) sebesar $321.57 \mathrm{~mm} /$ bulan dengan curah hujan terendah pada bulan Juli yaitu 292.00 $\mathrm{mm} /$ bulan dan curah hujan tertinggi pada bulan Juni $373.7 \mathrm{~mm} / \mathrm{bulan}$. Jumlah curah hujan selama penelitian berlangsung sudah memenuhi syarat tumbuh tanaman kolesom Menurut Seswita (2010) Tanaman kolesom dapat tumbuh pada dataran rendah sampai ketinggian tempat $1250 \mathrm{~m}$ di atas permukaan laut. Dengan curah hujan 2000 - $4000 \mathrm{~mm} /$ tahun atau $>166.6 \mathrm{~mm} / \mathrm{bulan}$.

Pembungaan merupakan faktor yang menyebabkan menurunnya kualitas pucuk kolesom dan membuat pucuk tidak layak untuk dipanen. Pada penelitian ini tanaman dipanen dengan interval panen 15 hari sekali, setelah pemanenan pertama ketika umur tanaman 30 HST. Pada 21 HST tanaman sudah mulai berbunga, sedangkan pada penelitian Anna (2010) tanaman kolesom berbunga pada 35 HST. Pada penelitian yang dilakukan Anna (2010) perlakuan interval panen 15 hari sekali diduga dapat memperlambat munculnya bunga tanaman kolesom. Tanaman yang tetap berbunga dengan interval panen 15 hari sekali diduga karena suhu yang tinggi pada siang hari, menurut Poerwanto (2014) suhu yang tinggi dan stress air dapat menginduksi pembungaan.

Bakteri yang banyak menyerang adalah Pseudomonas sp.. Bakteri ini dapat bertahan di dalam tanah dan dapat cepat berkembang biak pada keadaan tanah yang lembab. Toksin dan enzim yang dihasilkan oleh bakteri ini dapat melarutkan dinding sel akar dan dapat menyebabkan perubahan warna pada jaringan pengangkutan yang dapat dilihat jika batang dipotong (melintang) atau dibelah. Umumnya pertama kali gejala terlihat pada tanaman yang berumur kurang lebih 6 minggu. Gejala yang terlihat adalah daun-daun layu, dimulai dari daundaun muda. Pada bagian yang layu daging daun diantara tulang-tulang daun atau di tepi daun 
menguning, kemudian mengering dan akhirnya seluruh daun layu dan tanaman menjadi mati (Aisyah, 2012). Penanganan penyakit layu dengan mengeradikasi tanaman yang terkena penyakit dan membuangnya jauh dari areal pertanaman kolesom. Serangan hama belalang mulai tampak pada umur tanaman 28 HST. Serangan belalang mengakibatkan daun menjadi rusak. Kerusakan pada tanaman juga terjadi disebabkan karna adanya hewan ternak yang memasuki areal percobaan sehingga memakan bagian pucuk tanaman dan merusak bedengan.

\section{Persentase Hidup Tanaman Kolesom}

Rata-rata persentase tumbuh tanaman kolesom pada 30 HST memiliki nilai yang rendah, yaitu sebesar $60.6 \%$ (Tabel 2). Persentase tumbuh tanaman dapat dikatakan sangat baik apabila memiliki presentase diatas $90 \%$.

Tabel 2. Populasi tanaman kolesom pada setiap interval panen

\begin{tabular}{lccc}
\hline \multirow{2}{*}{$\begin{array}{l}\text { Dosis Pupuk } \\
(\%)\end{array}$} & \multicolumn{3}{c}{$\begin{array}{c}\text { Persentase Populasi Tanaman pada } \\
\text { Panen ke - }\end{array}$} \\
\cline { 2 - 4 } & $\begin{array}{c}\text { (30 HST) } \\
\text { (45 HST) }\end{array}$ & \begin{tabular}{c} 
(60 HST) \\
\hline
\end{tabular} & $\begin{array}{c}\text { H } \\
\text {---------- \% }\end{array}$ \\
\hline 50 & 69.0 & 46.0 & 38.0 \\
50 & 54.0 & 33.0 & 27.0 \\
100 & 55.0 & 28.0 & 24.0 \\
150 & 67.0 & 48.0 & 41.0 \\
200 & 58.0 & 43.0 & 35.0 \\
\hline Rata-rata & 60.6 & 39.6 & 33.0 \\
\hline
\end{tabular}

Keterangan : HST $=$ Hari Setelah Transplant

Presentase hidup tanaman yang rendah dan penurunan presentase hidup pada setiap interval panen, disebabkan karena terserangnya tanaman oleh bakteri Pseudomonas sp. yang menyerang sebagian besar tanaman. Pseudomonas sp. memiliki sifat tular tanah yang menyebabkan bakteri ini mudah menyebar dengan cepat pada tanaman kolesom. Bakteri yang menyerang tanaman kolesom pada penelitian ini diduga berasal dari bibit yang sebelumnya sudah terserang bakteri Pseudomonas sp., sehingga sebagian besar tanaman yang berada pada petak percobaan yang ditanami bibit yang sudah terserang bakteri mengalami kerusakan dan mati.

\section{Pengaruh Konsentrasi Nitrogen terhadap Pertumbuhan Vegetatif Kolesom}

Secara keseluruhan tanaman kolesom mengalami peningkatan tinggi selama penelitian. Pada Tabel 3 menunjukkan bahwa pemberian pupuk nitrogen dengan konsentrasi hingga 200\% dapat meningkatkan tinggi tanman, namun tidak memberikan hasil yang berbeda nyata dengan kontrol pada setiap interval panen.

Tabel 3. Pengaruh konsentrasi nitrogen terhadap tinggi tanaman dalam setiap taraf dosis pemupukan disetiap interval panen

\begin{tabular}{|c|c|c|c|}
\hline \multirow{3}{*}{$\begin{array}{l}\text { Dosis Pupuk } \\
(\%)\end{array}$} & \multicolumn{3}{|c|}{$\begin{array}{l}\text { Rata-rata Tinggi Tanaman per } \\
\text { Tanaman pada Panen ke - }\end{array}$} \\
\hline & 1 & 2 & 3 \\
\hline & (30 HST) & (45 HST) & $(60 \mathrm{HST})$ \\
\hline & \multicolumn{3}{|c|}{ 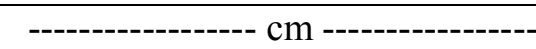 } \\
\hline 0 & 58.27 & 69.98 & 84.11 \\
\hline 50 & 53.86 & 74.07 & 88.78 \\
\hline 100 & 52.42 & 72.65 & 81.67 \\
\hline 150 & 53.59 & 73.44 & 92.83 \\
\hline 200 & 53.20 & 68.00 & 90.83 \\
\hline$\overline{\mathrm{KK}}(\%)$ & 60.6 & 39.6 & 33.0 \\
\hline $\mathrm{Uji}^{\mathrm{x}}$ & $\mathrm{tn}$ & $\operatorname{tn}$ & tn \\
\hline Pola ${ }^{y}$ & - & _- & \\
\hline
\end{tabular}

Keterangan : HST $=$ Hari Setelah Transplant, ${ }^{\mathrm{x}} \mathrm{Uji} \mathrm{F}$ untuk melihat pengaruh aplikasi pupuk $\mathrm{N}$ terhadap rata-rata tinggi tanaman; ${ }^{\mathrm{y}} \mathrm{Uji}$ lanjut menggunakan uji polynomial orthogonal; tn = tidak berbeda nyata; $\mathrm{KK}=$ Koefisien Keragaman.

\section{Pengaruh Konsentrasi Nitrogen terhadap Pucuk Kolesom}

Tabel 4 menunjukkan berdasarkan perhitungan statistik pemupukan dengan dosis $0 \%, 50 \%, 100 \%, 150 \%$ dan $200 \%$ pada setiap interval panen memiliki jumlah pucuk yang tidak berbeda nyata. Pemanenan pertama pada $30 \mathrm{HST}$ terdapat banyak pucuk yang sudah memenuhi kriteria panen pada tanaman dengan perlakuan

Tabel 4. Pengaruh konsentrasi nitrogen terhadap jumlah pucuk panen pada setiap interval panen

\begin{tabular}{|c|c|c|c|c|}
\hline \multirow{2}{*}{$\begin{array}{l}\text { Dosis } \\
\text { Pupuk (\%) }\end{array}$} & \multicolumn{3}{|c|}{$\begin{array}{l}\text { Rata-rata Jumlah Pucuk per } \\
\text { Tanaman pada Panen ke - }\end{array}$} & \multirow[b]{2}{*}{-Tota } \\
\hline & $\begin{array}{c}1 \\
(30 \mathrm{HST})\end{array}$ & $\begin{array}{c}2 \\
(45 \mathrm{HST})\end{array}$ & $\begin{array}{c}3 \\
(60 \mathrm{HST})\end{array}$ & \\
\hline 0 & 6.12 & 2.58 & 1.81 & 4.00 \\
\hline 50 & 7.42 & 3.54 & 1.56 & 3.80 \\
\hline 100 & 5.52 & 1.95 & 0.50 & 2.34 \\
\hline 150 & 17.04 & 3.94 & 2.47 & 8.46 \\
\hline 200 & 10.67 & 2.55 & 2.00 & 4.98 \\
\hline KK $(\%)$ & 22.51 & 23.07 & 22.09 & 22.03 \\
\hline $\mathrm{Uji} \mathrm{F}^{\mathrm{x}}$ & tn & tn & tn & tn \\
\hline Pola $^{y}$ & - & - & - & 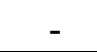 \\
\hline
\end{tabular}

Keterangan : HST $=$ Hari Setelah Transplant, ${ }^{x} \mathrm{Uji} F$ untuk melihat pengaruh aplikasi pupuk $\mathrm{N}$ terhadap rata-rata tinggi tanaman; ${ }^{\mathrm{Y}} \mathrm{Uji}$ lanjut menggunakan uji polynomial orthogonal; tn = tidak berbeda nyata; $\mathrm{KK}=$ Koefisien Keragaman. 
$0 \%$, 50\%, dan 100\% nitrogen. Tanaman dengan pemupukan $150 \%$ dan $200 \%$ nitrogen, memiliki lebih banyak pucuk dibandingkan dengan tanaman lainnya, namun belum memenuhi kriteria panen karena memiliki ukuran kurang dari $15 \mathrm{~cm}$.

Pada penelitian Anna (2010) menunjukan interaksi antara interval panen 15 hari sekali dan frekuensi pemupukan 3 kali $(0,30$, dan 60 HST) dengan dosis total $150 \mathrm{~kg}$ urea ha ${ }^{-1}$ dan $150 \mathrm{~kg}$ $\mathrm{KCl} \mathrm{ha}{ }^{-1}$ menghasilkan pucuk nyata terbaik (78.1 pucuk/tanaman dengan bobot panen total 307.673 g/tanaman) bila dilakukan dengan panjang pemanenan pucuk $10 \mathrm{~cm}$. Penelitian yang dilakukan Sugiarto (2006) diketahui bahwa panen kolesom dengan pangkas pucuk yang dipanen sebagai sayuran berukuran $15 \mathrm{~cm}$ dari ujung daun yang ditegakkan, dapat dilakukan mulai umur 8 MST dengan frekuensi panen 3 minggu sekali. Umur tanaman yang kurang, diduga menyebabkan pemanen dengan kriteria panen panjang pucuk 15 cm kurang maksimal.

Pemupukan nitrogen dengan berbagai dosis yang diberikan, memberikan hasil yang tidak berbeda nyata terhadap bobot pucuk panen pada setiap interval panen. Tabel 5 menunjukkan pada pemanenan yang dilakukan pada umur 45 HST dan $60 \mathrm{HST}$, bobot pucuk yang dihasilkan mengalami penurunanan dari pemanenan sebelumnya.

Tabel 5. Pengaruh konsentrasi nitrogen terhadap bobot pucuk panen pada setiap interval panen

\begin{tabular}{|c|c|c|c|c|}
\hline \multirow{2}{*}{$\begin{array}{l}\text { Dosis } \\
\text { Pupuk (\%) }\end{array}$} & \multicolumn{3}{|c|}{$\begin{array}{l}\text { Rata-rata Bobot Pucuk per } \\
\text { Tanaman pada Panen ke - }\end{array}$} & \multirow[t]{2}{*}{$\begin{array}{l}\text { Rata- } \\
\text { rata }\end{array}$} \\
\hline & $\begin{array}{c}1 \\
(30 \mathrm{HST})\end{array}$ & $\begin{array}{c}2 \\
(45 \mathrm{HST}\end{array}$ & $\begin{array}{c}3 \\
(60 \mathrm{HST})\end{array}$ & \\
\hline & 2400 & q & & \\
\hline $\begin{array}{l}\text { l } \\
50\end{array}$ & $\begin{array}{l}34.00 \\
53.75\end{array}$ & $\begin{array}{l}21.95 \\
19.71\end{array}$ & $\begin{array}{l}8.00 \\
8.45\end{array}$ & $\begin{array}{l}25.33 \\
27.00\end{array}$ \\
\hline 100 & 32.30 & 13.58 & 2.33 & 15.01 \\
\hline 150 & 62.93 & 26.40 & 9.75 & 31.60 \\
\hline 200 & 63.70 & 13.96 & 8.00 & 27.90 \\
\hline$\overline{\mathrm{KK}}(\%)$ & 18.44 & 23.94 & 22.87 & 18.10 \\
\hline $\mathrm{Uji}^{\mathrm{x}}$ & tn & tn & tn & tn \\
\hline Pola $^{y}$ & - & - & - & - \\
\hline
\end{tabular}

Keterangan : HST $=$ Hari Setelah Transplant, ${ }^{x} \mathrm{Uji} F$ untuk melihat pengaruh aplikasi pupuk $\mathrm{N}$ terhadap rata-rata tinggi tanaman; ${ }^{\mathrm{y}} \mathrm{Uji}$ lanjut menggunakan uji polynomial orthogonal; tn = tidak berbeda nyata; $\mathrm{KK}=$ Koefisien Keragaman.

Pada pemanenan terakhir ketika tanaman berumur $60 \mathrm{HST}$, pemberian pupuk $\mathrm{N}$ dengan berbagai dosis nitrogen yang diberikan, dapat menghasilkan bobot basah brangkasan dan tajuk yang berbeda nyata. Menurut Sumiati (2007) unsur hara $\mathrm{N}$ merupakan bahan pembangun protein, asam nukleat, enzim, nukleoprotein, dan alkaloid. Defisiensi N dapat membatasi pembelahan sel. tersedianya $\mathrm{N}$ dalam jumlah yang diperlukan tanaman mendukung perkembangan tanaman yang dapat meningkatkan bobot brangkasan dan tajuk kolesom. Pola respon bobot basah brangkasan dan tajuk terhadap perlakuan berbagai dosis $\mathrm{N}$ adalah kuadratik. Pola respon kuadratik pada peubah yang diamati dapat diartikan bahwa pemberian pupuk nitrogen pada dosis tertentu dapat meningkatkan bobot basah brangkasan dan tajuk sampai titik tertentu, sedangkan pemberian dengan dosis lebih lanjut akan mengurangi hasil bobot basah brangkasan dan tajuk. Hasil dari perhitungan analisis regresi didapatkan bahwa dosis $108.45 \mathrm{~kg} \mathrm{~N} \mathrm{ha}^{-1}$ memberikan hasil maksimum pada bobot basah tanaman kolesom sebesar $1308.91 \mathrm{~g} /$ tanaman.

Data bobot basah batang pada Tabel 5 menunjukkan bahwa perlakuan berbagai dosis pupuk $\mathrm{N}$ berpengaruh nyata terhadap bobot basah batang. Perlakuan berbagai dosis pupuk $\mathrm{N}$ memberikan pola respon kuadratik terhadap bobot basah batang, tajuk dan tanaman (Gambar 3a, 3b dan 3c), dengan sekitar $30 \%$ hasil tanaman (bobot) dipengaruhi \% perlakuan dosis pemupukan nitrogen.

Bobot basah daun merupakan salah satu komponen dari produksi daun segar kolesom. Bobot daun yang semakin besar akan meningkatkan produksi biomassa. Biomassa merupakan semua bahan kasar yang diperoleh dari semua proses yang terjadi dalam pertumbuhan tanaman. Menurut Herrera dan Taisma (1998) menyatakan bahwa dalam kondisi ketersediaan air yang terbatas kolesom mengalami perubahan metobolisme dari C3 menjadi CAM dan menggugurkan daun karena mekanisme adaptasi kekeringan. Gugurnya daun akibat adaptasi kekeringan yang dilakukan tanaman kolesom mempengaruhi bobot basah daun.

Tabel 5 menunjukkan bahwa pemupukan $\mathrm{N}$ dengan beberapa taraf dosis berpengaruh nyata terhadap bobot basah daun. Bobot daun dengan perlakuan dosis N 200\% memiliki bobot daun tertinggi dibandingkan dengan perlakuan lainnya dan 1.5 kali lebih besar dibandingkan kontrol. Hal ini menunjukkan penambahan dosis nitrogen hingga taraf $200 \%$ dapat meningkatkatkan bobot basah daun. Pola respon linier pada bobot basah daun dapat diartikan semakin tinggi dosis $\mathrm{N}$ yang diberikan, maka semakin tinggi bobot basah daun.

Pengamatan bobot basah akar dilakukan diakhir penelitian. Dosis pemupukan 150\% memberikan hasil terbaik dibandingkan dengan perlakuan lainnya, namun secara statistik Tabel 6 menunjukkan bahwa perlakukan dosis pemupukan 
$\mathrm{N}$ yang diberikan tidak mempengaruhi bobot akar yang dihasilkan, hal ini diduga disebabkan karena jumlah unsur $P$ yang diberikan pada setiap perlakuan sama. Pada penelitian Mualim et al.(2009), Perlakuan NK (tanpa P) yang memberikan rata-rata rasio bobot kering tajuk/akar terendah dan berbeda nyata dengan perlakuan kontrol, NPK, NP (tanpa K) dan PK (tanpa $\mathrm{N}$ ), mengindikasikan bahwa $\mathrm{P}$ berperan dalam pertumbuhan tajuk kolesom. Menurut Marschner (1995) tanaman pada saat fase pertumbuhan vegetatif memerlukan suplai karbohidrat, dimana dalam pembentukan dan translokasinya membutuhkan energi berupa adenosin trifosfat (ATP) yang berasal dari P. Menurut Mualim (2009) pertumbuhan tajuk kolesom yang lebih baik akan menekan pertumbuhan akar, karena alokasi asimilat lebih ditujukan untuk pembentukan bagian tajuk yaitu batang, cabang, dan daun kolesom. Pada penelitian ini bagian tajuk yang dominan menggunakan asimilat yaitu bagian pucuk tanaman, sehingga dengan pembentukan pucuk tanaman yang semakin tinggi akan mengurangi terbentuknya akar.

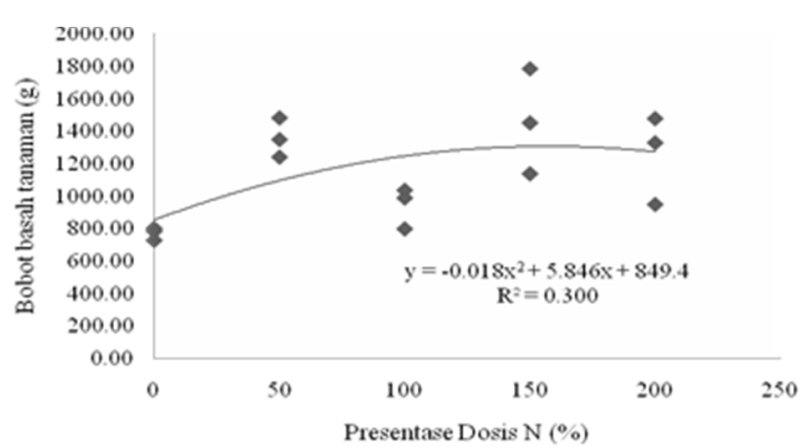

(a)

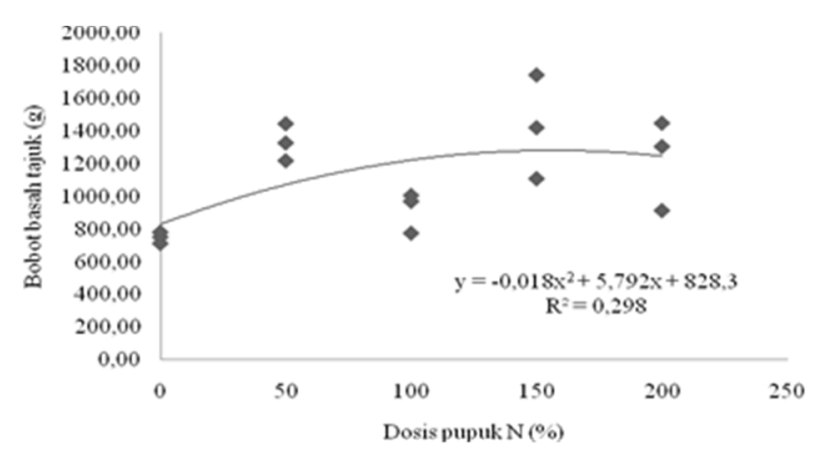

(b)

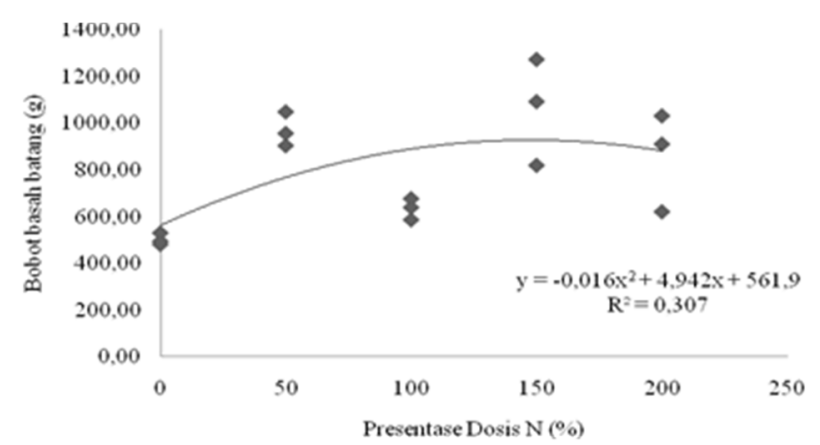

(c)

Gambar 3 (a) sebaran perlakuan berbagai dosis $\mathrm{N}$ terhadap bobot basah brangkasan per tanaman; (b) sebaran perlakuan berbagai dosis $\mathrm{N}$ terhadap bobot basah tajuk per tanaman; (c) sebaran perlakuan berbagai dosis $\mathrm{N}$ terhadap bobot basah batang per tanaman

Tabel 6. Pengaruh perlakuan benih setelah disimpan 7 bulan terhadap tinggi bibit dan jumlah daun pada 1-3 minggu setelah tanam di persemaian

\begin{tabular}{|c|c|c|c|c|c|}
\hline \multirow{3}{*}{ Dosis Pupuk $(\%)$} & \multicolumn{5}{|c|}{ Rata-rata Bobot Basah } \\
\hline & Batang & Daun & Akar & Tajuk & Brangkasan \\
\hline & $(1)$ & $(2)$ & (3) & $(1+2)$ & $(1+2+3)$ \\
\hline & \multicolumn{5}{|c|}{ 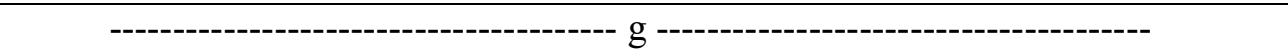 } \\
\hline 0 & 502.78 & 246.22 & 21.1 & 749.00 & 770.20 \\
\hline 50 & 970.11 & 361.67 & 24.5 & 1331.80 & 1365.30 \\
\hline 100 & 634.83 & 283.33 & 29.7 & 918.20 & 940.30 \\
\hline 150 & 1061.89 & 364.08 & 31.1 & 1426.00 & 1457.10 \\
\hline 200 & 854.92 & 369.00 & 27.0 & 1223.90 & 1251.00 \\
\hline$\overline{\mathrm{KK}}(\%)$ & 14.37 & 17.41 & 19.17 & 14.49 & 13.96 \\
\hline $\mathrm{Uji}^{\mathrm{x}}$ & $* *$ & $*$ & th & $* *$ & $* *$ \\
\hline Pola $^{y}$ & $\mathrm{~K}$ & $\mathrm{~L}$ & - & $\mathrm{K}$ & $\mathrm{K}$ \\
\hline
\end{tabular}

Keterangan : HST $=$ Hari Setelah Transplant, ${ }^{x}$ Uji F untuk melihat pengaruh aplikasi pupuk N terhadap bobot basah

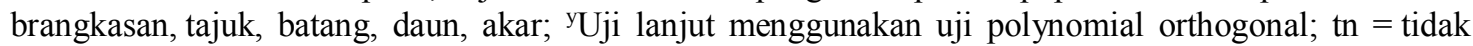
berbeda nyata; * = berbeda nyata $(\mathrm{P}<0,05) ; * *$ = berbeda sangat nyata $(\mathrm{P}<0,01) ; \mathrm{K}=$ kuadratik pada uji lanjut polynomial orthogonal; $\mathrm{KK}=$ Koefisien Keragaman. 


\section{KESIMPULAN}

Aplikasi dosis N 0-200\% pada tanaman kolesom dapat meningkatkan secara kuadratik bobot basah brangkasan, tajuk dan batang, serta dapat meningkatkan secara linier bobot basah daun. Perlakuan dosis $\mathrm{N}$ tidak berpengaruh nyata terhadap tinggi tanaman, jumlah cabang primer, dan bobot basah akar. Dosis rekomendasi pemupukan $\mathrm{N}$ pada tanaman kolesom yang ditanam di inceptisol Dramaga adalah $108.45 \mathrm{kgN}$ $\mathrm{ha}^{-1}$, dengan nilai R2 sebesar 0.300 .

\section{DAFTAR PUSTAKA}

[BMKG] Badan Meteorologi Klimatologi dan Geofisika. 2016. Data iklim wilayah Darmaga bula Juni - Agustus 2016. Stasiun Klimatologi Darmaga, Bogor.

Acquaah, G. 2004. Horticulture: Principles and Practices.. Pearson Prentice Hall. New Jersey.

Aisyah, I. 2012. Mengenal gejala penyakit layu pada tanaman dan cara menanganinya. http://vedca.siap.web.id. [24 Agustus 2017].

Anna, I.W. 2010. Produksi Pucuk Kolesom pada Berbagai Interval Panen dan Frekuensi Pemupukan $\mathrm{N}$ dan K. [Skripsi]. Institut Pertanian Bogor. Bogor.

Aziz, S.A. 2011. Panduan Budidaya Kolesom Organik (Talinum triangulare (Jacq.) Willd.) (Good Agriculture Pratices) yang Baik. Departemen Agronomi dan Hortikultura, Institut Pertanian Bogor. Bogor.

Darwati, I., M. Rahardjo, Rosita. 2000. Produktivitas som jawa (Talinum paniculatum Gaertn.) pada beberapa komposisi bahan organik. Jurnal Littri 6. (1): $1-4$.

Mualim, L, S.A. Aziz, M. Melati .2009. Kajian Pemupukan NPK dan Jarak Tanam pada Produksi Antosianin Daun Kolesom. J Agron Indonesia. 37 (1): 55-61.
Mualim, L., S.A. Aziz, S. Susanto, M. Melati. 2012. Aplikasi Pupuk Inorganik Meningkatkan Produksi dan Kualitas Pucuk Kolesom pada Musim Hujan. J Agron Indonesia. 40 (2): 160-166.

Mualim, L. 2009. Kajian pemupukan NPK dan jarak tanam pada produksi antosianin daun kolesom. [Tesis]. Institut Pertanian Bogor. Bogor.

Rifai, M.A. 1994. Talinum triangulare (Jacq.) Wild. In Siemonsma, J.S., K. Piluek (eds). Plant Resources of South-East Asia; No.8 Vegetables. Pudoc Scientific Publishers, Wageningen, Netherlands. p. 268-269.

Sarief, E.S. 1986. Ilmu Tanah Pertanian. Pustaka Buana. Bandung.

Seswita, D. 2010. Som Jawa (Talinum paniculatum) ginseng indonesia penyembuh berbagai penyakit. Warta Penelitian dan Pengembangan Tanaman. 16(2).

Sugiarto, N.T. 2006. Pengaruh panen dan umur panen pada produksi pucuk Kolesom (Talinum triangulare (Jacq.) Willd.). [Skripsi]. Institut Pertanian Bogor. Bogor.

Sumiati, E., O.S. Gunawan. 2007. Aplikasi pupuk hayati mikoriza untuk meningkatkan efisiensi sarapan unsur hara NPK serta pengaruhnya terhadap hasil dan kualitas umbi bawang Merah. J. Hort. 17(1): 34-42

Susanti, H. 2006. Produksi biomassa dan bahan aktif kolesom (Talinum triangulare (Jacq.) Willd) pada berbagai asal bibit, dosis pupuk kandang ayam, dan komposisi media tanam. [Disertasi]. Institut Pertanian Bogor. Bogor.

Susanti, H., S.A. Aziz, M. Melati. 2008. Produksi biomassa dan bahan bioaktif kolesom (Talinum triangulare (Jacq.) Wild.) dari berbagai asal bibit dan dosis pupuk kandang ayam. Buletin Agronomi. 36 (1) : 48-55.

Wijaya, K.A. 2008. Nutrisi Tanaman Sebagai Penentu Kualitas Hasil dan Resistensi Alami Tanaman. Prestasi Pustaka. Jakarta. 